\title{
Egyéves halálozás miokardiális infarktus után
}

\author{
Vértes András
}

\author{
ESZSZK, I. sz. Belgyógyászat-Kardiológia, Budapest \\ Levelezési cím: Dr. Vértes András, e-mail: vertesandras@eszszk.hu
}

Miokardiális infarktust (AMI) követően az utóbbi évtizedben jelentősen csökkent a korai halálozás, amely elsősorban az intervenciós beavatkozások eredménye. Már az infarktus utáni első 30 napot követően a kardiovaszkuláris halálozás emelkedik, és a statisztikák alapján az egyéves halálozás az európai adatoknál jelentősen rosszabb. A közlemény a késői magas halálozás okait keresi, és megoldási javaslatokat tesz.

Kulcsszavak: kardiovaszkuláris mortalitás, miokardiális infarktus, beteg edukáció

\section{Myocardial infarction mortality after one year}

The early mortality after myocardial infarction has significantly decreased in the last decade, primarily due to interventional cardiology. After the first 30 days after acute myocardial infarction the cardiovascular mortality increases and based on statistics the one-year mortality is significantly higher in Hungary then European data shows it. The publication aims to find the reasons of increased mortality and offers possible solutions.

Keywords: cardiovascular mortality, myocardial infarction, patient education

A kardiovaszkuláris (CV) eredetü halálozás maradt a leggyakoribb haláloknak Európában (1). Az utóbbi években minden országban jelentősen javultak a CV mortalitási és morbiditási adatai. Már vannak olyan európai országok, ahol a daganatok halálozása megelőzi a CV-halálozást (Franciaország, Svájc). A 2016-os európai átlag adatok szerint a CV-okból bekövetkező halálozás 45\% (férfiaknál 40\%, nőknél 49\%) volt a teljes halálozási adatokhoz viszonyítva. Magyarországon az utóbbi 10 évben 12,1\%-kal csökkent a CV-mortalitás (1. ábra). Az Apollo-vizsgálat az amerikai, francia, angol, és a svéd biztosítási adatok segítségével elemezte a halálozási adatokat több, mint 150000 infarktust elszenvedett beteg adatain keresztül. A 3 éves kardiovaszkuláris halálozás, miokardiális infarktus, stroke együttes előfordulása Svédországban 19,8\%, USA-ban 18,2\%, Franciaországban $16,7 \%$, és Angliában 21,3\% volt (2). A Svéd Infarktus Regiszter valós élet adatait T. Jernberg és munkatársai dolgozták fel. A vizsgálatban 108 315 beteg vett részt. Az infarktust követően az első év kumulatív esemény rátája 18,3\% volt. A nem fatális AMI előfordulása ezen belül $55,5 \%$, a nem fatális stroke $13,4 \%$, és a halál előfordulása $31 \%$ volt.

Szignifikánsan gyakoribb volt időskorban (80 év felett,) illetve a magas rizikójú egyének esetében a CV-események előfordulása (3).
A Magyar Nemzeti Szívregiszter elindítása Jánosi András professzor nevéhez füződik. A Nemzeti Szívinfarktus Regiszter 2014-es adatai szerint 2014-ben 10458 beteget regisztráltak, akiknek 45,67\%-a STEMI, 54,32\%-a NSTEMI-diagnózissal kerül rögzítésre. A regisztrált betegek száma 2010 és 2014 között folyamatosan emelkedett, 2407-ről 10 458-re, amely elsősorban az egyre növekvő jelentési fegyelemnek köszönhető $(4,5)$.

Az infarktus korai halálozása az intervenciós centrumok, a szervezett STEMI-ügyelet és a PCl fejlődésével jelentősen csökkent. A 2015-es füredi Kardiológiai Kongresszuson számoltak be az AMI hosszú távú kórlefolyásának eredményeiről (1. táblázat).

STEMI esetén az 1 éven belül bekövetkező halálozás több mint a fele (57\%) 30 napon belül következik be! NSTEMI esetén az 1 éven belüli halálozás több mint fele (60\%) 30 nap és 1 év között következik be! A 30 napon belül bekövetkező események 72,5\%-a kórházon kívül történt.

Az adatokból egyértelműen kiderül, hogy Magyarországon a kórházi halálozási adatok hasonlóak a fejlett nyugati országokéhoz, de az 1 éves halálozás adatai már messze rosszabbak voltak.

A közleményben arra próbáltam keresni a választ, hogy milyen okok állhatnak ennek a ténynek a hátterében.

Ehhez segítséget adott az ESC hasonló célú felhívása (6). 


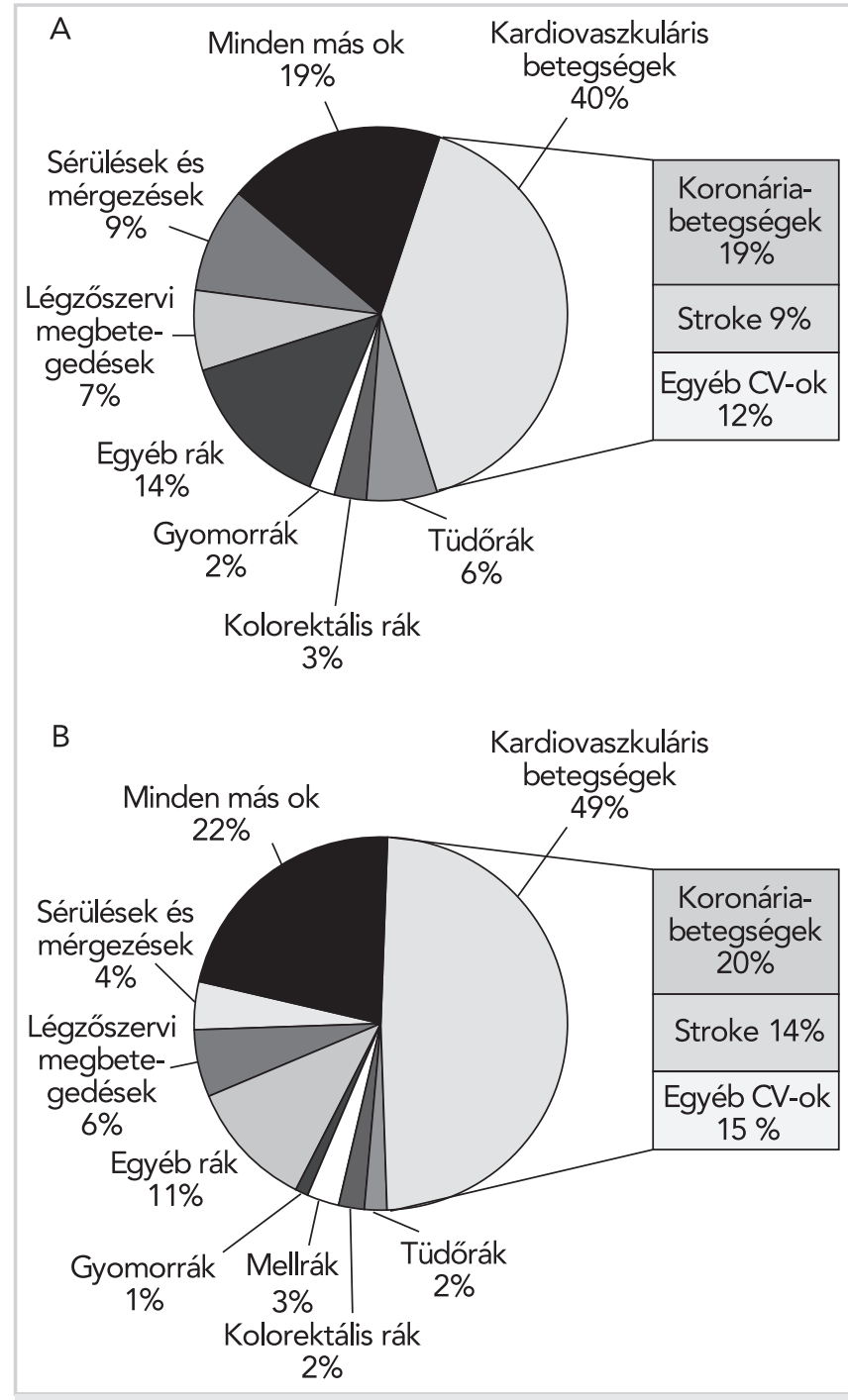

1. ÁBRA: Halálokok Európában (A) férfi, (B) nő 2015-ben. Forrás: WHO Mortality Database

(From: Cardiovascular disease in Europe: epidemiological update 2016. Eur Heart J. 2016; 37 (42): 3232-3245. doi: 10.1093/eurheartj6ehw334 Eur Heart J. Published on behalf of the European Society of Cardiology. All rights reserve. please e-mail: journals.permissions@oup.com

1. TÁBLÁZAT: Az AMI hosszú távú kórlefolyásának eredményei

\begin{tabular}{|l|c|c|c|}
\hline & $\begin{array}{c}\text { Kórházi } \\
\text { halálozás } \\
\text { (\%) }\end{array}$ & $\begin{array}{c}\mathbf{3 0} \text { napos } \\
\text { halálozás } \\
\mathbf{( \% )}\end{array}$ & $\begin{array}{c}\text { 1 éves } \\
\text { halálozás } \\
\mathbf{( \% )}\end{array}$ \\
\hline AMI & 5,6 & 10,5 & 21,7 \\
\hline STEMI & 6,4 & 11,0 & 19,6 \\
\hline NSTEMI & 4,9 & 9,63 & 23,9 \\
\hline
\end{tabular}

\section{Betegedukáció}

A betegeknek tisztában kell lenniük betegségük eredetével, a kezelési célokkal, stratégiával, az életmód-változtatás szükségességével.

Jelenleg, elsősorban az orvosok időhiánnyal magyarázva a betegek nem ismerik meg ezeket a tényezőket. In- farktus esetében sikeres intervenciót követően a betegek jelentős része - elsősorban a fiatal, aktív dolgozók - úgy gondolják, hogy ők teljesen egészségesek, meggyógyultak, és akár néhány nap múlva mehetnek dolgozni. Nem alakul ki betegségtudat. A betegek nincsenek felvilágosítva a szekunder prevenció fontosságáról, és arról, hogy ezt életük végéig fokozottan alkalmazniuk kell. Nem ismerik a megfelelő táplálkozás fontosságát. A betegedukáció fontosságát az ESC Prevenciós ajánlás alapján I. erősségü. Kiemelésre kerül, hogy az egyéni betegedukáció mellett a populációs megközelítés (internet, televízió) ugyancsak I./A ajánlás (7).

Segíthetne a betegoktatás terén, ha minden beteg, aki távozik az intervenciós centrumokból, vagy kardiológiai osztályokról PCl, AMI-t követően, a zárójelentésen feltüntetnénk a gyógyszerelési javaslat mellett (a clopidogrel szedésének 1 éves javaslata sikeresen beépült a rendszerbe), a rizikófaktorok célértékét, az életmód-változtatás fontosságát, a rendszeres kardiológiai ellenőrzés javaslatát is.

Sok esetben nem elégséges a beteg oktatása, be kell hívni a családot is, és közösen kell elvégezni a felvilágosítást. Az orvosnak, vagy nővérnek vissza kell kérdezni, annak lemérésére, hogy a beteg megértette-e az ismertetés lényegét.

A szóbeli felvilágosítás mellett a beteg írásos anyagot is kapjon. Az internet a betegoktatás fontos tényezőjévé vált. A telemedicina interaktív segítséget tud nyújtani az infarktust elszenvedett betegek folyamatos edukációjában. Az internet természetesen veszélyes is lehet, ki kell szűrni a nem evidenciákkal megerősített, és inkább profitszerzésre irányuló anyagok terjedését.

\section{Rehabilitáció}

Bizonyított, hogy a rehabilitáció is fontos szerepet játszik a beteg állapotának stabilizálásában, progressziójának lassításában, a szövődmények kialakulásának megakadályozásában, valamint a mortalitás csökkentésében. Különösen igaz ez a fizikai aktivitást középpontba állító rehabilitációs programok esetében.

A kedvező hatások ellenére Európában meglehetősen alacsony a rehabilitációba bevont betegek száma. Az European Cardiac Rehabilitation Inventory Survey $(n=28,2009)$ eredményei alapján a rehabilitáció első szakasza a vizsgált országok 86 százalékában (hazánkban is) az aktív fekvőbeteg-ellátás keretében ajánlott, az ambuláns és fekvőbeteg-ellátásban zajló második rehabilitációs szakasz csak 15 országban volt elérhető, a részvételi arány pedig 30\% alatti volt. Az EUROASPIRE IV-vizsgálat elemzésében, AMI után csak a betegek 41\%-a vesz részt szekunder prevenciós programban vagy rehabilitációban! Nem volt szignifikáns különbség az életkori megosztásban (8).

Simon Éva Kardiovaszkuláris Prevenciós és Rehabilitációs 2017/1 számában közölte (9), hogy Infarktus 
Regiszter Fekvőbeteg Rehabilitációs Adatbázis kialakításában jelenleg a rehabilitációs osztályok/részlegek fele egyelőre önkéntes alapon vesznek részt, amelynek kapcsán a szívinfarktust túlélő és rehabilitációban részt vevő betegek mintegy 9\%-áról van további információnk. Jánosi és munkatársai 2015. évröl összegyűjtött adataiból kiderül, hogy a betegek közel fele (44,45\%) otthonába távozott, közülük 26,4\% másik kórházi osztályra került. A fekvőbeteg-rehabilitációs kezelés lehetőségét a betegek 49\%-ának ajánlották fel, de ezt a betegek kevesebb, mint 8\%-a vette igénybe.

Az ambuláns rehabilitáció ideális alanyai azok a betegek, akik a rehabilitáció fenntartó szakaszában vannak, akik közepes, vagy alacsony kockázati csoportba esnek, akiknél a család kifejezett támogató szerepet játszik, akik az ellátó hely közelében laknak, akiknél a fekvőbeteg-státusz jelentős pszichés terhelést, stresszt okozna, akik már a rehabilitációs fázisban részben, vagy teljesen képesek visszatérni a munkavégzéshez. Jelenleg nem minden kardiológiai rehabilitációs centrumban végeznek ambuláns foglakozást, pedig ez elsősorban, akiknek nem szükséges fekvőbeteg-háttér, és a lakhelyéhez közel van lehetőség, ez jelentős előnyökkel járhat.

Javasolt, hogy az intervenciós osztályok minél több beteget referáljanak a rehabilitációs osztályok felé, és az összes infarktuson átesett betegnek biztosítsák a fekvőbeteg, vagy az ambuláns rehabilitációs foglakozás lehetőségét.

\section{Szekunder prevenció}

Minden AMI-t elszenvedett betegnek a szekunder prevencióval kapcsolatos életmód-változtatást és gyógyszeres kezelést alkalmazni kell a szakmai ajánlásoknak megfelelően. A szekunder prevenció elkezdését már az akut kezelésnél meg kell kezdeni, és folytatni kell az egész élet folyamán.

A szekunder prevenciós kezelés eredményessége függ az intervenciós orvos, a kezelést végző kardiológus és a gondozást végző háziorvos együttmüködésétől.

A cukorbetegség, a magas koleszterinértékek, és a vérnyomás ellenőrzése és a gyógyszeres kezelés rendszeres ellenőrzést igényel. A terápiás célértékeket rendszeresen kell ellenőrizni.

Miokardiális infarktust követően alkalmazni kell az ESC Prevenciós és Rehabilitációs ajánlását (6), illetve a STEMI (10) és NSTEMI kezelési ajánlását.

Az AMI késői halálozás csökkentésében ugyancsak fontos szerepe van a gyógyszer-adherenciának. A trombocitaaggregáció-gátló kezelést, AMI-t, PCl-t követően sikerült a gyakorlatba átvenni, a betegek már a legritkább esetben hagyják el idő előtt. A statinoknak a célértékek elérése mellett az ateroszklerózis regressziójában is szerepe van. Sajnos ennek elfogadása még a kardiológusok között sem teljesen elfogadott.
A betegek kezelése során a háziorvos fontos szerepe, hogy a megfelelő kezelést a beteg tartósan kapja, és minél ritkábban történjen gyógyszercsere.

Erősíteni kellene az együttműködést, az akut ellátást végző fekvő- és a gondozást végző ambuláns ellátóhely, valamint a kardiológus és a családorvos között.

- Jobban kellene ösztönözni a szakmai irányelvek betartását, amelyben egyaránt fontos szerepe van az egészségpolitikának, a finanszírozásnak, az orvos-továbbképzésnek és a beteg oktatásnak.

- Lehetővé kellene tenni a jövőben, hogy minden szívinfarktust szenvedett beteg számára elérhető legyen az intézeti/vagy ambuláns preventív/rehabilitációs kardiológiai programokban való részvétel.

Kívánatos lenne prevenciós centrumok kialakítása ebből a célból, ahogy ezt az európai szakmai irányelvek is javasolják.

- Minden beteg számára ki kell hangsúlyozni, szóban és írásban is az életmód-változtatás jelentőségét, és az egész élet során szükséges gyógyszerelés fontosságát és időt kell szakítani a betegek oktatására.

\section{Irodalom}

1. Nick Townsend, Lauren Wilson, et al. Cardiovascular disease in Europe: epidemiological update 2016. Europ Heart J 2016; 37: 3232-3245. https://doi.org/10.1093/eurheartj/ehw334

2. Hemingway $\mathrm{H}$. International comparison of outcomes among 140,880 patients stable after acute $\mathrm{Ml}$; real-world evidence from electronic health and administrative records. Presented at: European Society of Cardiology Congress; 2014; August 31. Barcelona

3. Jernberg T, Hasvold P, Henriksson M, et al. Cardiovascular risk in post-myocardial infarction patients: nationwide real world data demonstrate the importance of a long-term perspective. Eur Heart J 2015 May 14; 36(19): 1163-70. https://doi.org/10.1093/eurheartj/ehu505

4. Jánosi A, Póth A, Zorándi Á, et al. A Szívinfarktus miatt kezelt betegek ellátásának jellemzői. Nemzeti Szívinfarktus Regiszter. 2013 Card Hung 2015; 45: 1-4.

5. Jánosi A, Póth A, Zorándi Á, et al. Szívinfarktus miatt kezelt betegek ellátásának vizsgálata Magyarországon a rendelkezésre álló egészségügyi adatok alapján. Orv Hetil 2016; 157(3): 89-93.

6. Piepoli MF, Corrá U, Dendale P, et al. Challenges in secondary prevention after acute myocardial infarction: A call for action. Eur Journal of Prev Card 2016; 23(18): 1994-2006. https://doi org/10.1177/2047487316663873

7. Piepoli MF, ${ }^{*}$ Hoes AW, Agewall S, et al. 2016 European Guidelines on cardiovascular disease preventionin clinical practice. Eur J of Prev Card 2016; 23(11): NP1-NP96. https://doi.org/10.1093/eurheartj/ehw106

8. Bjarnason-Wehrens B, McGee H, Zwisler AD et al. Cardiac rehabilitation in Europe: results from the European Cardiac Rehabilitation Inventory Survey. Eur J of Cardi Prev and Rehab 2010; 17: 410-418. https://doi.org/10.1097/HJR.0b013e328334f42d.

9. Simon É, Simon A. A Nemzeti Szívinfarktus Regiszter Fekvőbeteg Rehabilitációs Adatbázis kezdeti eredményei és tanulságai. Kardiovaszkuláris prevenció és rehabilitáció 2017; 1.

10. Ibanez B, James S, Agewall S, et al. 2017 ESC Guidelines for the management of acute myocardial infarction in patients presenting with ST-segment elevation. Eur Heart J 2017; 00: 1-66. https:// doi.org/10.1093/eurheartj/ehx393 